\title{
An Analysis on the Different Use of Discourse Markers in Spontaneous and Non-spontaneous Utterances
}

\author{
Ratna Padmi Trihartanti \\ Politeknik Negeri Bandung \\ Tanti_nio@yahoo.com
}

\begin{abstract}
It is impossible for us not to use discourse markers in our utterance because without being realized we need them to make our utterance more meaningful. The importance and the function of discourse marker haven't been known widely by students, and for the reason the research entitled 'An Analysis the use of discourse markers in the spontaneous and non-spontaneous utterance's students. The aims of the research are: the first is to analyze the most discourse markers used in spontaneous utterance's students. The second is to analyze the use of discourse marker in non-spontaneous utterance, and the third is to analyze discourse markers used wrongly in spontaneous and nonspontaneous utterance's students. After being analyzed, it could be concluded that both spontaneous and non- spontaneous utterances, discourse marker 'hmm' as 'filler' is mostly used. The other discourse markers used by students are 'yes', 'oh', 'well', 'I see'. Meanwhile the most discourse markers used wrongly by the students in their utterances are 'hmm', 'yeah', 'oh' and 'ah'. The influence of Indonesian language such as: 'he..he..he', 'ya..ya..ya' could also be seen from discourse markers used by the students and it makes the utterance 'clumsy'. Discourse markers used in spontaneous utterance are more various, but at the same time the mistakes made in using them are also more.
\end{abstract}

Keywords: discourse markers, utterance, spontaneous, nonspontaneous, 'filler'

\section{INTRODUCTION}

Not all utterances flow well because sometimes participant cannot reply the questions rapidly. The moment where speaker or hearer confuses how to answer will create 'an empty space', and this situation makes the utterance seem to be 'clumsy'. Some of us will use a word or words to fill the 'empty space' such as: 'hmm', 'oh', 'well' and others, and in their development they called discourse markers. Some of them add the meaning of the utterance and some of them don't. As we know that we have two ways of communication, namely: spoken (spontaneous) and written (non-spontaneous). We may guess that it is in spontaneous utterance discourse markers could be found a lot since sometimes we have to think our reply a little bit longer, yet they are also found a lot in nonspontaneous ones. The aims of the research are to analyze the most discourse markers used in spontaneous utterance's students, to analyze the use of discourse marker in nonspontaneous utterance, and to analyze discourse markers used wrongly in spontaneous and non-spontaneous utterance's students. The data were taken from 61 utterances of the first year students of English Department.

\section{LITERATURE REVIEW}

Discourse markers develops rapidly and through some years a lot of researchers conducted research on discourse markers and their findings have given significant role in language, especially in development of linguistics field. Previous study on discourse markers shows that 'well' is mostly used as a face-threat mitigator (Trihartanti \& Damayanti, 2013). Meanwhile, the use of 'oh' is mostly used as' pure surprise'. From this study, it can be found that the use of discourse marker 'oh' was used more than 'well' since 'oh' is also more commonly used in Indonesian conversations than 'well.' Another finding is, though 'oh' is mostly used in Indonesian conversation, it is used wrongly more than the use of 'well'.

\section{THEORETICAL FRAMEWORK}

There are some theories of discourse markers used in the present research, namely: Heritage (1984), Aijmer (2002), Jucker (1984), and also the theory from Brown and Levinson (1987) such as: 'quality hedge', 'relevance hedge'. Those are negative Politeness strategies, and their main function is to avoid Face Threatening Acts (FTAs).

'Ohs' as discourse markers have a lot of functions in utterance; therefore, 'ohs' are often used as they can make utterance more expressive. According to Heritage (1984) 'oh participates 'in a wide variety of "language games": noticing; having one's attention drawn to something; remembering; being reminded, informed or corrected; arriving at discoveries and realizations of various kinds and many more'. Anyway, only three of 'ohs' discussed. The first is 'oh' as 'pure surprise'. It is used when one of participants is surprised after getting an explanation or a statement from another participant. 'Oh' also can be used when the speaker finds something that she/he never thinks of having it. The next function of 'oh' is as 'arriving at a realization'. This function works when the first speaker in utterance wants to mention the name of someone, or thing, but she/he doesn't remember, and before the first speaker finishes, the second speaker mentions the name that is not remembered by the first. Another function of 'oh' is as 'genuine surprise'. It 
shows the disappointment of speaker after getting/receiving information that is different from what she/he wants.

Another discourse marker used is 'well' and according to Jucker (1997) there are 4 functions of 'well' such as: a frame marker, qualifier, a face -threat mitigator, and a pause filler. 'Well as 'a frame marker occurs when speaker wants to change a new topic of utterance. 'Well' is used because it is considered can mitigate or minimize the effect of utterance in order not to threaten another speaker. The next 'well' is 'qualifier'. It is used if the first speaker asks question incompletely, and for that reason the next speaker cannot reply completely. Another use of 'well' is 'a face-threat mitigator', and it happens when the second speaker wants to express her/his disagreement or reject to the first speaker's statement, request, or if both participants are in confrontation. To mitigate confrontation the speaker uses 'well' to lessen the impact of utterance. The last use of 'well' is as 'pause filler'. 'Pause filler' used when a speaker doesn't know how to reply the question/ statement from another participant, then she/he uses 'well' to bridge interactional silence.

Another discourse marker is 'hmm'. Aijmer (2002) stated that ' $\mathrm{hmm}$ ' has 2 functions. The first is to fill 'an empty space' in order not to create silence in utterance. The second, it is to express 'hesitation' of speaker because she/he hesitates to respond.

Discourse marker 'yes' has some functions, two of them are as 'response of question yes/no', and as 'agreement'. According to Aijmer (2002) 'yes' functions as 'response of question yes/no' if speaker answers the question from another speaker by replying 'yes'/'no'. 'Agreement' is used if speaker agrees with statement of another participant.

Discourse marker 'I think' as 'a quality hedges' is used if speaker is not sure about his/her opinion; therefore he/she uses 'I think' as ' quality hedges' as it has been stated by Brown \& Levinson (1987) in their theory of Politeness, and 'qualityhedges' is one of negative Politeness strategies.

'Relevance hedges' is used as discourse marker to avoid Face Threatening Act (FTAs) because the speaker wants to change the topic of utterance. To minimize FTAs, 'relevance hedges' is used as it stated by Brown and Levinson (1987).

\section{DISCUSSIONS AND FINDINGS}

Quality method is used to conduct the research since the data relates closely to analysis. There are 31 utterances used as the data. 16 utterances are spontaneous means that 32 students directly uttered in front of the class and while they were doing that, researcher recorded theirs. Meanwhile, 15 utterances conducted by different students from a different class. The students worked in pairs, and they had 10 minutes to prepare the utterance before writing them down. After those activities had finished, the next step is to select, classify, and analyze discourse markers used by the students. The last activity is to make some tables to describe and to analyze the meaning of discourse markers.

After being analyzed, it can be concluded that discourse markers mostly used in spontaneous and nonspontaneous utterances are: 'hmm' as 'pause filler' and it followed by 'yes', 'oh', 'well', 'I see', and 'I think'. Meanwhile the most discourse markers used wrongly in both of utterances are: 'hmm', 'yeah', 'oh', and 'ah'. The influence of Indonesian language can be seen clearly in the student' utterances, for example: 'he..he..he', and 'ya..ya..ya'. Below are some examples of the students' utterances.

Table 1: 3 Data of Spontaneous Utterances

\begin{tabular}{|c|c|c|c|}
\hline No & Utterance & $\begin{array}{l}\text { Discourse } \\
\text { markers }\end{array}$ & Meaning \\
\hline 1 & $\begin{array}{l}\text { S: 'I am fine, } \\
\text { thank you. How } \\
\text { about } \\
\text { you?' } \\
\text { M: 'Euu... I am } \\
\text { fine, 'euu'..what and } \\
\text { are you doing in } \\
\text { the last holiday?' }\end{array}$ & $\begin{array}{l}\text { 'euu...euu' } \\
\text { mean 'hmm' }\end{array}$ & $\begin{array}{l}\text { The first 'hmm' in the } \\
\text { utterance functions as } \\
\text { 'hesitation'because } \\
\text { hesitates to answer S's } \\
\text { question. The second 'hmm' } \\
\text { functions as 'a pause filler' }\end{array}$ \\
\hline 2 & $\begin{array}{l}\text { S: 'Oh, then?' } \\
\text { M: 'And then } \\
\text { 'euu'...I saw } \\
\text { 'euum' many } \\
\text { treesand } \\
\text { 'euu'...flowers } \\
\text { and I take } \\
\text { pictures with my } \\
\text { friends' }\end{array}$ & $\begin{array}{l}\text { 'euu'...euum', } \\
\text { and 'euu'mean } \\
\text { 'hmm' }\end{array}$ & $\begin{array}{l}\text { All 'hmms' in the utterance } \\
\text { functions as 'a pause filler' }\end{array}$ \\
\hline 3 & $\begin{array}{l}\text { S: 'Ya, you know } \\
\text { my activity is } \\
\text { boring' } \\
\text { R: 'Oh, I see' }\end{array}$ & 'oh, I see' & $\begin{array}{l}\text { 'oh, I see' functions as } \\
\text { 'acceptance' of R' statement. }\end{array}$ \\
\hline
\end{tabular}

Table 2: 3 Data of Non-Spontaneous Utterances

\begin{tabular}{|c|c|c|c|}
\hline No & Utterance & $\begin{array}{l}\text { Discourse } \\
\text { markers }\end{array}$ & Meaning \\
\hline 1 & $\begin{array}{l}\text { F: 'But you know } \\
\text { that the } \\
\text { demonstration } \\
\text { colored with } \\
\text { criminal acts...' } \\
\text { A: 'Emm...yes } \\
\text { you are right..' } \\
\text { F: 'Yeaahhh...I } \\
\text { hope we can } \\
\text { change it } \\
\text { although it's } \\
\text { difficult. By the } \\
\text { way you } \\
\text { went tndramayu, right }\end{array}$ & $\begin{array}{l}\text { 'emm' means } \\
\text { 'hmm', 'yeaah, } \\
\text { and 'by the } \\
\text { way' }\end{array}$ & $\begin{array}{l}\text { The function of 'hmm' in the } \\
\text { utterance is as a pause filler'. } \\
\text {-Another discourse marker is } \\
\text { 'yeaah' functions as } \\
\text { 'agreement' from F. } \\
\text {-The last discourse marker is } \\
\text { 'by the way' functions as } \\
\text { 'relevance hedge', to mitigate } \\
\text { the utterance because F wants } \\
\text { to change the topic. }\end{array}$ \\
\hline
\end{tabular}


Table 1, Cont.

2 R: 'Hmm', but you know, we spent most of our time inside the room and the

bus...'I think' it is not a big problem...'

S: 'Well', R, I am sorry I have to go now.

See you next time'

A: 'My organization and I gave some

food and other daily needs to flood

victims in Indramayu'

F: ' Woow your activities

gave more

benefit'

A: 'Yes, of course'...

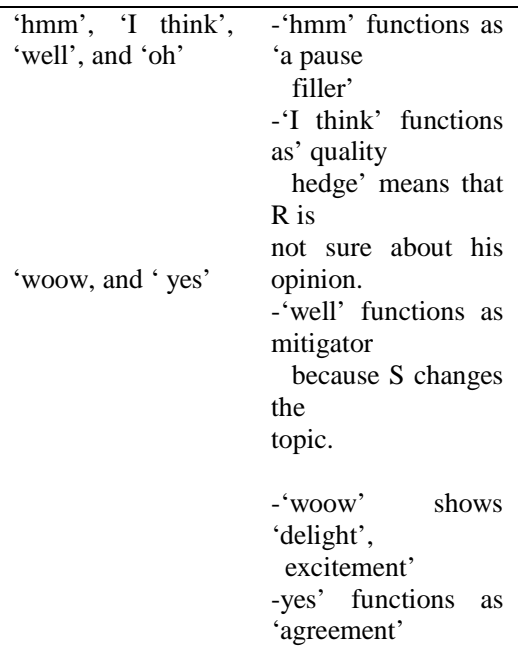

- 'well' functions as mitigator

because $\mathrm{S}$ changes the

topic.

-'woow' shows

'delight',

excitement'

-yes' functions as

'agreement'

compared with our culture, since Indonesian's influence could be seen clearly on students' utterance.

\section{REFERENCES}

Aijmer, K. (2002). English Discourse Particles: Evidence from a corpus. Studies in Corpus Linguistics. US: John Benjamins.

Brown, P. \& Levinson, S. C. (1987). Politeness: Some universals in language usage. Cambridge: Cambridge University Press.

Fraser, B. (1988). Types of English discourse markers. ActaLinguistica Hungaria,19-38.

Heritage, J. (1998). Oh-prefaced responses to inquiry. Language in Society, 27, 291- 334. The United States of America: Cambridge University Press.

Jucker, A. H. (1997). The discourse marker well in the history of English. English Language Linguistics, 1, 91-110.

Table 3: 2 Data of wrong Discourse Markers in Students'

\begin{tabular}{|c|c|c|c|}
\hline \multicolumn{4}{|c|}{ Utterances } \\
\hline No & Utterance & $\begin{array}{l}\text { Discourse } \\
\text { Markers }\end{array}$ & Meaning \\
\hline 1 & $\begin{array}{l}\text { A: 'Really? When?' } \\
\text { M: 'Last weekend, I } \\
\text { have told you' } \\
\text { A: 'Oya,.he...he. Wow } \\
\text { that's lovely' }\end{array}$ & $\begin{array}{l}\text { ‘oya', means } \\
\text { ‘oh, yes, }\end{array}$ & $\begin{array}{l}\text {-the use of 'oya' in this } \\
\text { utterance is wrong. To } \\
\text { answer the statement of } \\
\text { M, A must use discourse } \\
\text { marker 'Really?' }\end{array}$ \\
\hline 2 & $\begin{array}{l}\text { L: '...what are you } \\
\text { doing?' } \\
\text { M: 'Y Yeah! Just did } \\
\text { daily activities' }\end{array}$ & ‘yeah' & $\begin{array}{l}\text {-the use of 'yeah' in this } \\
\text { utterance is not correct. It } \\
\text { should be 'well' }\end{array}$ \\
\hline
\end{tabular}

Table 4: 2 Data of Indonesian Influence on Students' Utterances

\begin{tabular}{|c|c|c|c|}
\hline No & Utterance & $\begin{array}{l}\text { Discourse } \\
\text { markers }\end{array}$ & Meaning \\
\hline 1 & $\begin{array}{l}\text { M... 'Ooooh, he..he..he, } \\
\text { both of them are } \\
\text { different level...' }\end{array}$ & $\begin{array}{l}\text { 'ooh, } \\
\text { he..he..he }\end{array}$ & $\begin{array}{l}\text {-'he..he..he' is not English } \\
\text { discourse marker. It is } \\
\text { Indonesian discourse } \\
\text { marker which functions to } \\
\text { mitigate the utterance. }\end{array}$ \\
\hline 2 & $\begin{array}{l}\text { I: 'I went to Santoloyo } \\
\text { beach at Garut' } \\
\text { J: 'Oh } \\
\text { ya..ya..ya..ya..but..' }\end{array}$ & $\begin{array}{l}\text { 'oh, } \\
\text { уа..уа..уа..уа' }\end{array}$ & $\begin{array}{l}\text {-'oh ya..ya..ya'is } \\
\text { Indonesian language which } \\
\text { means 'yes' }\end{array}$ \\
\hline
\end{tabular}

\section{CONCLUSION}

Discourse markers are very important in utterance, and students have to understand their functions well. From the data has been analyzed. It is clear that some students have not understood well discourse markers. Those can be explained in Cross Cultural Understanding, Speaking, and Text Analysis and Grammar subjects. How to teach them can be related or 